\title{
ABSENTEE VOTING, MOBILIZATION, AND PARTICIPATION
}

\author{
JEFFREY A. KARP \\ SUSAN A. BANDUCCI \\ Universiteit van Amsterdam
}

\begin{abstract}
Liberal absentee laws are designed to make voting easier, which should stimulate turnout. Using data from the National Election Studies, we test the hypothesis that persons who choose to vote early are already highly motivated to participate in the political process. We find support for this hypothesis, which raises questions about the extent to which liberal absentee laws can expand the electorate. Furthermore, contrary to past research, we see the Republican advantage in absentee voting as a result of self-selection rather than party mobilization.
\end{abstract}

Empirical examinations of low turnout have focused on the various costs of voting (Piven \& Cloward, 1988; Teixeira, 1992; Wolfinger \& Rosenstone, 1980). Because theoretical models of voting typically characterize the decision to vote as a function of collective and individual benefits weighed against the cost of voting (Downs, 1957; Riker \& Ordeshook, 1968), lowering the costs of voting is seen as one way of increasing turnout. Relaxing eligibility requirements for absentee voters and allowing permanent absentee status so that voters can cast their ballots by mail are reforms designed to make voting easier; these reforms have the potential to stimulate turnout. Initially, absentee laws were intended for those persons who would otherwise not be able to vote in person, such as servicemen away from home and, later, persons with disabilities and elders. Yet, in recent years, an increasing number of states have relaxed these restrictions to make voting more convenient for everyone. In 11 states, citizens can cast an

Authors' Note: The research for this article was completed while at the University of Waikato. An earlier version of this article was prepared for presentation at the annual conference of the Southwestern Social Science Association, March 31-April 3, 1999, San Antonio, Texas. Authorship is equal; names are listed in reverse alphabetical order. We are grateful to the InterUniversity Consortium for Political and Social Research for providing us with the National Election Studies and Randall Partin for providing data on gubernatorial elections.

AMERICAN POLITICS RESEARCH, Vol. 29 No. 2, March 2001 183-195

(C) 2001 Sage Publications, Inc. 
absentee ballot for any reason (Oliver, 1996). Where these reforms have been implemented, there has been a substantial increase in the number of voters choosing to vote by mail or vote early in person. In California and Washington, the proportion of voters casting a mail ballot increased to more than 20\% in the 1996 presidential election (California Secretary of State, 1996; Washington Secretary of State, 1996). In Oregon, almost half of those participating in the 1996 presidential election chose to do so by mail (Oregon Secretary of State, 1996). In Texas, where voters can cast their votes in person up to 3 weeks before a general election, $30 \%$ have chosen to do so since 1991 (Stein, 1998).

Reformers anticipate that the adoption of more permissive absentee laws allowing voters to participate through the mail at their convenience will help to stimulate turnout. Whether permissive absentee laws produce higher turnout or serve as a substitute for voting in person is not clear. Dubin and Kalsow (1996) found that the passage of a 1977 bill in California that allowed all voters access to absentee ballots had the effect of increasing the level of absentee voting but did not increase the level of overall participation (p. 388). Stein and GarciaMonet (1997) found evidence of a small but significant increase in turnout as a result of early voting in Texas (p. 665). Patterson and Caldeira (1985) suggested that absentee voting and its impact on turnout are sensitive to partisan efforts to mobilize voters. Oliver (1996) suggested that the adoption of permissive absentee laws makes it easier for parties to mobilize their supporters, which, in turn, helps to stimulate turnout. Republicans, according to Oliver, have been using the liberalization of absentee voter eligibility as an opportunity to mobilize their supporters by making it easier for them to register and vote absentee. This mobilization thesis helps to explain some of the recent come- from-behind victories where apparent Democratic victories have been upset after the counting of absentee votes. If this is the case, liberal absentee laws have the potential of increasing overall turnout to the Republicans' advantage (see also Jeffe \& Jeffe, 1990).

Surveys suggest that the higher income, older, and more conservative voters are more likely to use the absentee process (Cook, 1991; Oliver, 1996) and vote early in person (Stein 1998). Early voters in Texas demonstrate a greater interest in politics and stronger partisan and ideological ties than Election Day voters (Stein, 1998). These 
individuals are also more likely to vote. Therefore, relaxing absentee requirements may only serve to increase voting among the groups already most likely to participate. This hypothesis is consistent with current research on turnout that suggests that relaxed registration requirements (Brians \& Grofman, 1999; Calvert \& Gilchrist 1993), early voting (Stein \& Garcia-Monet, 1997), and all mail elections (Karp \& Banducci, 2000) provide a convenience for those already likely to vote by virtue of their education, age, and income rather than attracting the disadvantaged to the polls. Therefore, the potential for easy absentee voting to expand the electorate may be limited.

The answer to whether voters who would not otherwise participate are taking advantage of permissive absentee laws, as electoral reformers intend, has to date remained elusive given the reliance on data aggregated at either the county or precinct level (Dubin \& Kalsow, 1996; Patterson \& Caldeira, 1985; Richardson \& Neeley, 1996; Stein \& Garcia-Monet, 1997). In the following analysis, we take advantage of a design that allows us to examine whether absentee laws attract politically inactive individuals either through convenience or mobilization. This allows us to address the question of whether the Republican advantage in absentee voting is due to the mobilization of Republican voters or whether the advantage is due to self-selection.

\section{DATA AND METHOD}

Studies that examine the impact of electoral laws on turnout at the individual level have relied on the Voter Supplement of the Current Population Survey (CPS) (see, e.g., Oliver, 1996; Mitchell \& Wlezien, 1995; Wolfinger \& Rosenstone, 1980). The large number of cases sampled from every state allows for sufficient variation in electoral arrangements such as registration requirements and large samples of subgroups of voters such as absentee voters. However, the lack of appropriate measures for party activity and partisanship in the CPS means that party mobilization and party identification cannot be properly measured. Therefore, hypotheses about partisan advantages in absentee voting are difficult to test. Moreover, relying on proxy variables of party activity such as whether a state has open or closed primaries as indicators of party mobilization (see Oliver, 1996) compli- 
cates the interpretation of the results when the proxy variable is not validated.

The data used in previous studies can be improved in two ways. First, to remedy problems with appropriate measures of party identification and party mobilization, survey data measuring these variables accurately are necessary. Second, a large national sample is required to allow for variation in electoral laws and a sufficient number of subgroups of voters. To meet these two requirements, we employ data from the National Election Studies (NES) that are pooled across five successive elections. Pooling the data generates a sample of absentee voters sufficiently large for analysis $(N=446)$ and covers 42 states. These data allow us to better test the influence of mobilization on absentee voting as well as test additional hypotheses. To measure mobilization, we use whether respondents report having been contacted by anyone about registering to vote or getting out to vote (see Rosenstone \& Hansen, 1993). ${ }^{1}$ This question has been asked in the past seven NESs.

Rather than party mobilization of unlikely voters, we expect those already engaged in politics to be more likely to take advantage of the convenience of absentee voting. Therefore, we expect persons with higher education and those who are politically active to be more likely to vote absentee. We measure political activity by constructing a scale of five items measuring political participation $(\alpha=.67)$. These items consist of the following: whether individuals attend political meetings, display political propaganda, work for a political campaign, donate money to candidates, or donate money to political parties (see appendix). Similarly, we expect partisans, whether Republican or Democrat, to be more likely to vote absentee than nonpartisans. Therefore, we include a dummy variable for independents and another dummy variable for Republicans (with those identifying with the Democratic Party as the referent category).

We also employ contextual variables to measure the competitiveness of statewide races. If the mobilization thesis is correct, we would expect to find higher rates of absentee voting in states with competitive races. To measure competitiveness, we identify Senate and gubernatorial races where the plurality winner was separated by less than $5 \%$ of the vote. The variable takes on a value of 2 when both races are competitive, 1 when either race is competitive, and 0 if neither are 
competitive. Two additional variables are used to control for states that did not have a gubernatorial or Senate race so that the effective reference category for the competitive variables is made up of noncompetitive races. A dummy variable is also included to distinguish midterm from presidential elections. ${ }^{2}$

To account for variations in state absentee laws, three categories are used following Oliver's (1996) classification (see appendix for details). ${ }^{3}$ Dummy variables are used to identify states that allow anyone to vote absentee as well as for states that have some restrictions (reference category consists of states with the most restrictive absentee laws).

Our dependent variable is based on three choices: whether to abstain, vote in person, or vote absentee. Multinomial logit (MNL) could be used to estimate a three-choice model. However, MNL assumes the independence of irrelevant alternatives (IIA). Therefore, we would have to assume that the probability of voting in person is completely independent of whether one has the option of voting absentee. Such an assumption may be unrealistic given that one of the primary reasons for adopting liberal absentee laws was to help compensate those who find going to the polls too difficult. An alternative method that does not carry the same assumption is to omit one of the alternatives and estimate three binomial logit models. Omitting the alternative from the model is inefficient but will produce the same results as MNL if the IIA assumption is valid (Greene, 1997, p. 921). ${ }^{4}$ Hence, we estimate three binomial logit models-Vote in Person and Abstain, Vote Absentee and Abstain, and redundantly, Vote Absentee and Vote in Person. This method is less efficient but more conservative than MNL. ${ }^{5}$

\section{RESULTS}

Table 1 displays the results from the above models. To aid the interpretation of the logit coefficients, the derived probabilities for each of the independent variables are presented in Table 2. The difference between the minimum and maximum probabilities for a given variable are calculated by holding the remaining independent variables constant at their means or modes. 
TABLE 1

Likelihood of Voting at Polling Place and Voting Absentee Using Pooled NES ${ }^{\text {a }}$ (1990-1998)—Logistic Regression Coefficients

\begin{tabular}{|c|c|c|c|c|c|c|}
\hline \multirow[b]{2}{*}{ Republican } & \multicolumn{2}{|c|}{$\begin{array}{l}\text { Probability } \\
\text { of Voting at } \\
\text { Polling Place } \\
\text { (vs. Abstain) }\end{array}$} & \multicolumn{2}{|c|}{$\begin{array}{l}\text { Probability } \\
\text { of Voting } \\
\text { Absentee } \\
\text { (vs. Abstain) }\end{array}$} & \multicolumn{2}{|c|}{$\begin{array}{c}\text { Probability } \\
\text { of Voting Absentee } \\
\text { (vs. Voting at } \\
\text { Polling Place) }\end{array}$} \\
\hline & 0.05 & $(0.06)$ & $0.33 *$ & $(0.13)$ & 0.21 & $(0.11)$ \\
\hline Independent & $-0.81 * *$ & $(0.09)$ & $-0.67 * *$ & $(0.24)$ & 0.04 & $(0.23)$ \\
\hline Disabled & $-0.51 * *$ & $(0.14)$ & -0.08 & $(0.31)$ & $0.56^{*}$ & $(0.28)$ \\
\hline Student & 0.07 & $(0.12)$ & $0.61 *$ & $(0.27)$ & $0.63^{* *}$ & $(0.24)$ \\
\hline Non-White & $-0.16^{*}$ & $(0.08)$ & 0.15 & $(0.19)$ & 0.25 & $(0.17)$ \\
\hline Male & 0.06 & $(0.05)$ & -0.08 & $(0.13)$ & -0.09 & $(0.11)$ \\
\hline Married & $0.40 * *$ & $(0.06)$ & $0.33^{*}$ & $(0.13)$ & -0.16 & $(0.11)$ \\
\hline Stable resident & $0.55^{* *}$ & $(0.06)$ & $0.34 *$ & $(0.15)$ & -0.13 & $(0.14)$ \\
\hline 31 to 40 years & $0.40^{* *}$ & $(0.08)$ & 0.02 & $(0.22)$ & -0.37 & $(0.20)$ \\
\hline 41 to 50 years & $0.73^{* *}$ & $(0.09)$ & 0.33 & $(0.23)$ & -0.18 & $(0.21)$ \\
\hline 51 to 60 years & $1.19^{* *}$ & $(0.10)$ & $1.02 * *$ & $(0.25)$ & 0.17 & $(0.22)$ \\
\hline 61 to 70 years & $1.34 * *$ & $(0.11)$ & $1.65 * *$ & $(0.24)$ & $0.70^{* * *}$ & $(0.21)$ \\
\hline 71 to 80 years & $1.37 * *$ & $(0.12)$ & $2.01 * *$ & $(0.24)$ & $1.01 * *$ & $(0.22)$ \\
\hline 81 years and above & $1.19 * *$ & $(0.17)$ & $2.43 * *$ & $(0.30)$ & $1.64 * *$ & $(0.26)$ \\
\hline Education & $0.35^{* *}$ & $(0.02)$ & $0.42 * *$ & $(0.04)$ & $0.13^{* *}$ & $(0.04)$ \\
\hline Politically active & $0.66^{* *}$ & $(0.06)$ & $0.85^{* *} *$ & $(0.10)$ & $0.16^{* *}$ & $(0.05)$ \\
\hline Contact & $0.96^{* *}$ & $(0.07)$ & $0.72 * *$ & $(0.15)$ & -0.21 & $(0.12)$ \\
\hline Competitiveness & $0.12 *$ & $(0.06)$ & 0.03 & $(0.15)$ & 0.10 & $(0.13)$ \\
\hline No gubernatorial race & -0.08 & $(0.07)$ & 0.25 & $(0.18)$ & $0.45^{* *}$ & $(0.17)$ \\
\hline No Senate race & $-0.15^{* *}$ & $(0.06)$ & -0.16 & $(0.13)$ & 0.09 & $(0.11)$ \\
\hline Midterm election & $-1.23^{* *}$ & $(0.07)$ & $-0.96^{* *}$ & $(0.18)$ & 0.27 & $(0.16)$ \\
\hline Expanded eligibility & $0.24 * *$ & $(0.09)$ & $1.09^{* *}$ & $(0.20)$ & $1.03 * *$ & $(0.17)$ \\
\hline Universal eligibility & $0.14^{*}$ & $(0.06)$ & $1.55^{* *}$ & $(0.14)$ & $1.57 * *$ & $(0.12)$ \\
\hline Constant & $-1.65^{* *}$ & $(0.14)$ & $-5.41 * *$ & $(0.34)$ & -4.16 & $(0.31)$ \\
\hline \multicolumn{7}{|l|}{ Proportional reduction } \\
\hline Nagelkerke psuedo $R^{2}$ & .35 & & .41 & & .14 & \\
\hline$-2 \log$ likelihood & $11,099.95$ & & $2,681.44$ & & $3,040.75$ & \\
\hline$n$ & 8,281 & & 3,693 & & 5,463 & \\
\hline
\end{tabular}

SOURCE: American National Election Studies, 1990, 1992, 1994, 1996, 1998 (see Miller, Kinder, Rosenstone, \& National Election Studies, 1992, 1993; Rosenstone, Miller, Kinder, \& National Election Studies, 1995; Rosenstone, Kinder, Miller, \& National Election Studies, 1998; Sapiro, Rosenstone, \& National Election Studies, 1999).

NOTE: Standard errors are in parentheses.

a. NES = National Election Studies.

$* p<.05 . * * p<.01$

The results show little support for the hypothesis that absentee voting depends on mobilization. Being contacted significantly influences 
TABLE 2

Potential Impact of Voting at Polling Place and Voting Absentee

\begin{tabular}{lccc}
\hline \hline & $\begin{array}{c}\text { Polling Place } \\
\text { (vs. Abstain) }\end{array}$ & $\begin{array}{c}\text { Absentee } \\
\text { (vs. Abstain) }\end{array}$ & $\begin{array}{c}\text { Absentee } \\
\text { (vs. Polling Place) }\end{array}$ \\
\hline Republican & .01 & .02 & .00 \\
Independent & -.15 & -.02 & .00 \\
Disabled & -.09 & -.01 & .01 \\
Student & .01 & .06 & .02 \\
Nonwhite & -.03 & .01 & .00 \\
Male & .01 & -.01 & .00 \\
Married & .07 & .02 & .00 \\
Stable resident & .10 & .02 & .00 \\
31 to 40 years & .07 & .00 & -.01 \\
41 to 50 years & .12 & .03 & .00 \\
51 to 60 years & .17 & .11 & .00 \\
61 to 70 years & .19 & .22 & .02 \\
71 to 80 years & .19 & .30 & .04 \\
81 years and above & .20 & .41 & .06 \\
Education & .47 & .38 & .02 \\
Politically active & .22 & .76 & .02 \\
Contact & .11 & .07 & .00 \\
Competitiveness & .03 & .00 & .00 \\
No gubernatorial race & -.01 & .02 & .00 \\
No Senate race & -.03 & -.01 & .01 \\
Midterm election & -.26 & -.05 & .03 \\
Expanded eligibility & .04 & .12 & .06 \\
Universal eligibility & .02 & .20 & \\
\hline NOTE: Estings & & & .00 \\
\hline
\end{tabular}

NOTE: Estimates are derived from Table 1 by taking the difference between the minimum and maximum probabilities holding all other variables at their means and modes.

the probability of voting but does not help to distinguish between those voting in person and those voting absentee. Similarly, elections where parties are most likely to mobilize voters, such as competitive statewide races or presidential elections, increase the likelihood of voting in person but do not significantly increase the likelihood of voting absentee. Only in the absence of a gubernatorial race are citizens more likely to vote absentee than in person. Thus, absentee voting does not appear to be related to mobilization. Instead, those who are likely to vote by virtue of their age and education are also likely to vote absentee. In fact, higher education increases the probability of voting absentee. Similarly, elders who have a high probability of voting are more likely than younger voters to take advantage of absentee laws. 
Those older than 61 years are significantly more likely than those younger than 31 years to vote absentee than vote in person.

In addition, those who are more politically active, as measured by the political activity index, are more likely to vote, as expected, and more likely to vote absentee than the politically inactive. The full impact of political activity is evident in Table 2, which shows that the difference in the probability of voting (over abstaining) between the most and least politically active is .76. One might interpret this result as evidence for mobilization, because the politically active are targeted usually by political parties (Rosenstone \& Hansen, 1993, pp. 163-169). Although this may be the case, we still see significant effects for political activity while controlling for party contact and competitiveness, which suggests that political activity has an independent effect. This result supports the hypothesis that those already likely to vote are taking advantage of mailing in the vote, suggesting that liberal absentee laws will not do much to expand the electorate to include the politically inactive.

We do, however, find evidence that absentee laws help increase the likelihood of voting for those who might otherwise be inconvenienced by going to the polls. The potential for absentee laws to stimulate turnout among groups not likely to vote is largely limited to the persons with disabilities and students. Persons with disabilities are the only group that are less likely to vote in person but are more likely to vote absentee when compared with other groups. Although students are not significantly less likely to vote in person than nonstudents, they are more likely to vote absentee. In contrast, absentee laws appear to do very little to encourage voting among groups that are significantly less likely to vote in person, such as non-Whites or independents.

As the positive coefficients for expanded and universal show, individuals residing in states with relaxed absentee laws are more likely to vote, whether it be in person or by absentee, than citizens in other states. This suggests that the relationship between permissive absentee laws and overall turnout could, in part, be spurious. Higher turnout in these states could be due to a more progressive and participatory political culture that also led to the adoption of liberal absentee laws. However, the effect of universal and expanded absentee laws is greatest between not voting and voting and voting absentee. For example, there is an increase of .20 in the probability of voting absentee when 
universal laws are in place versus an increase of .02 in voting in person. As a test of Oliver's mobilization hypothesis, we explored interactions between state laws and mobilization but found no significant increase in voting absentee.

When all of these factors are taken into account, we find no significant partisan differences in choosing to vote absentee compared with voting in person. Removing political activity and education from the model produces a significant difference between Republicans and Democrats $(p=.01)$. The differences, however, are not substantial; Republicans are expected to be 1.3 times more likely to vote absentee (conditional on voting in person) than are Democrats. ${ }^{6}$ This suggests that, all other things being equal, the Republican bias discovered by others may have been due more to self-selection than mobilization (see Patterson \& Caldeira, 1985, p. 781; for evidence on a partisan bias in early voting in Texas, see Stein \& Garcia-Monet, 1997). Together, these results undermine the conventional wisdom that the Republican Party is benefiting by mobilizing absentee voters. Rather, highly motivated voters who might otherwise vote in person are taking advantage of liberal absentee voting rules.

\section{DISCUSSION}

Overall, these findings suggest that self-selection plays a greater role in determining who votes absentee than does party mobilization. We conclude that persons who vote early are likely to be educated, active in politics, and partisan. This is consistent with the voting-behavior literature that finds that persons possessing these characteristics are more likely to have made their minds up early in a campaign (Converse, 1962; Finkel, 1993). Liberal absentee laws do appear to help stimulate turnout among certain groups, such as persons with disabilities and students. Yet, the extent to which overall turnout can be increased beyond these groups is doubtful. More likely, only those who are politically motivated (and thus likely to vote) will make plans in advance to vote absentee. If liberal absentee laws encourage parties to mobilize their supporters by sending out absentee applications, the potential for increasing turnout will depend largely on whether parties activate more than the easiest and closest at hand. If we are correct in suggesting that absentee voting is highest among 
those groups already likely to vote, the electorate may not be expanded by absentee voting at all; instead, simply more voters are choosing to vote by mail. In 1996, almost half of Oregon voters, one third of Washington voters, and one fifth of California voters cast absentee votes. Even though absentee voting increased, overall turnout declined. In all three states, these levels of absentee voting are higher than in previous presidential election years; nonetheless, overall turnout declined between the 1992 and 1996 elections.

\section{APPENDIX}

Politically active: a summated scale $(\alpha=.67)$ ranging from 0 to 5 based on affirmative responses to each of the following five questions: Did you wear a campaign button, put a campaign sticker on your car, or place a sign in your window or in front of your house? Did you go to any political meetings, rallies, speeches, dinners, or things like that in support of a particular candidate? Did you do any (other) work for one of the parties or candidates? During an election year people are often asked to make a contribution to support campaigns. Did you give money to an individual candidate running for public office? Did you give money to a political party during this election year?

Contact: During the campaign this year, did anyone talk to you about registering to vote or getting out to vote? Yes $=1,0$ otherwise.

Absentee: Did you vote in person or by absentee ballot? If respondent voted (1990, 1992, 1994, 1998); if respondent voted before election day (1996).

Stable resident: Lived at residence less than 2 years $=1,0$ otherwise.

Education: 7-point scale.

Republican: Strong, weak, or lean Republican $=1 ; 0$ otherwise.

Independent: Does not identify with either the Republican or Democratic Party.

All dichotomous variables such as male, non-White, married, student, and disabled are coded 0 when the characteristic is absent and 1 when it is present.

Competitiveness: Plurality winners in both Senate and gubernatorial races won by more than $5 \%$ of the vote $=0$, plurality winner in either Senate or gubernatorial race won by less than $5 \%$ of the vote $=1$, plurality winners in both Senate and gubernatorial races won by less than $5 \%$ of the vote $=2$. Data on gubernatorial elections come from Congressional Quarterly (1998) and data on U.S. Senate races are from Statistical Abstract of the United States.

Universal:Arizona, California, Hawaii, Iowa, Nevada, Oklahoma, Oregon, Texas, Washington, Wyoming

Expanded: Colorado, Michigan, New Mexico, Ohio 


\section{NOTES}

1. Although the measure does not specifically ask if a respondent received an absentee ballot application in the mail, we feel that the question is broad enough to include those who did.

2. The model was also estimated with dummy variables for each election year to take into account unmeasured variables that may affect turnout. Estimating the model without these variables does not alter the results.

3. Some states have relaxed their requirements since 1992, but these states were already classified as universal. For example, Oregon, which falls under this category, modified its absentee law to allow any voter to maintain permanent absentee status.

4. Hausman's test for the validity of the independence of irrelevant alternatives (IIA) is based on the discrepancy between multinomial logit (MNL) and binomial logit results.

5. We estimated the model using MNL. The results were nearly identical, supporting the inference that the choices are indeed independent. Nevertheless, we report the binomial results as a more conservative test of our hypothesis.

6. The parameter estimate is .28 or $\left(\mathrm{e}^{28^{8 * 1}}\right)$. A test of further interactions between election year and partisanship activity also reveals a significant and stronger effect, even after controlling for education and political activity. Specifically, in 1996, Republicans are 1.7 times (e. $\left.{ }^{55^{* 1}}\right)$ as likely to vote absentee as Democrats.

\section{REFERENCES}

Brians, C. L. \& Grofman, B. (1999). When registration barriers fall, who votes? An empirical test of the rational choice model. Public Choice, 99, 161-176.

California Secretary of State. (1996). Election statistics [Online]. Available: http://www.ss.ca.gov/elections/elections_u.htm

Calvert, J., \& Gilchrist, J. (1993). Suppose they held an election and almost everybody came! PS: Political Science \& Politics, 24, 695-700.

Congressional Quarterly. (1998). Gubernatorial elections 1787-1997. Washington, DC: Author. Converse, P. E. (1962). Information flow and the stability of partisan attitudes. Public Opinion Quarterly, 26, 578-599.

Cook, G. (1991). Mail-order voters tip the balance in close elections. California Journal, 22, 101-103.

Downs, A. (1957). An economic theory of democracy. New York: Harper \& Row.

Dubin, J. A., \& Kalsow, G. A. (1996). Comparing absentee and precinct voters: A view over time. Political Behavior, 18, 369-411.

Finkel, S. E. (1993). Reexamining the "minimal effects" model in recent presidential campaigns. Journal of Politics, 55, 1-21.

Green, W. H. (1997). Econometric analysis (3rd ed.). New York: Prentice Hall.

Jeffe, D., \& Jeffe, S. B. (1990, November/December). Absence counts: Voting by mail. The American Enterprise, pp. 19-21.

Karp, J. A., \& Banducci, S. A. (2000). Going postal: How all mail elections influence turnout. Political Behavior, 22(3), 223-239.

Miller, W. E., Kinder, D. R., Rosenstone, S. J., \& the National Election Studies. (1992). American National Election Study, 1990: Post-election survey [Computer file]. Conducted by the 
University of Michigan, Center for Political Studies. 2nd ICPSR ed. Ann Arbor, MI: Inter-University Consortium for Political and Social Research [producer and distributor].

Miller, W. E., Kinder, D. R., Rosenstone, S. J., \& the National Election Studies. (1993). American National Election Study, 1992: Pre-and post-election survey (enhanced with 1990 and 1991 data) [Computer file]. Conducted by the University of Michigan, Center for Political Studies. ICPSR ed. Ann Arbor: University of Michigan, Center for Political Studies, and Inter-University Consortium for Political and Social Research [producers], 1993. Ann Arbor, MI: Inter-University Consortium for Political and Social Research [distributor].

Mitchell, G. E., \& Wlezien, C. (1995). The impact of legal constraints on voter registration, turnout, and the composition of the American electorate. Political Behavior, 17, 179-202.

Oliver, J. E. (1996). The effects of eligibility restrictions and party activity on absentee voting and overall turnout. American Journal of Political Science, 40, 498-513.

Oregon Secretary of State. (1996). Official election participation statistics November 5, 1996 [Online]. Available: http://www.sos.state.or.us/elections/nov596/other.info/totbycty.htm

Patterson, S. C., \& Caldeira, G. A. (1985). Mailing in the vote: Correlates and consequences of absentee voting. American Journal of Political Science, 29, 766-787.

Piven, F. F., \& Cloward, R. A. (1988). Why Americans don't vote. New York: Pantheon Books.

Richardson, L. E., \& Neeley, G. W. (1996). The impact of early voting on turnout: The 1994 elections in Tennessee. State and Local Government Review, 28, 173-179.

Riker, W. H., \& Ordeshook, P. C. (1968). A theory of the calculus of voting. American Political Science Review, 62, 25-42.

Rosenstone, S. J., \& Hansen, J. M. (1993). Mobilization, participation, and democracy in America. New York: Macmillan.

Rosenstone, S. J., Kinder, D. R., Miller, W. E, \& the National Election Studies. (1998). American National Election Study, 1996: Pre- and post election survey [Computer file]. 3rd release. Ann Arbor: University of Michigan, Center for Political Studies [producer], 1998. Ann Arbor, MI: Inter-University Consortium for Political and Social Research [distributor].

Rosenstone, S. J., Miller, W. E., Kinder, D. R., \& the National Election Studies. (1995). American National Election Study, 1994: Post-election survey (enhanced with 1992 and 1993 data) [Computer file]. Conducted by the University of Michigan, Center for Political Studies. 2nd ICPSR ed. Ann Arbor: University of Michigan, Center for Political Studies, and Inter-University Consortium for Political and Social Research [producers], 1995. Ann Arbor, MI: Inter-University Consortium for Political and Social Research [distributor].

Sapiro, V., Rosenstone, S. J., \& the National Election Studies. (1999). National Election Studies, 1998: Post-election study [data set]. Ann Arbor: University of Michigan, Center for Political Studies [producer and distributor].

Stein, R. M. (1998). Early voting. Public Opinion Quarterly, 62, 57-69.

Stein, R. M., \& Garcia-Monet, P. A. (1997). Voting early but not often. Social Science Quarterly, $78,657-671$.

Teixeira, R. A. (1992). The disappearing American voter. Washington, DC: Brookings Institution.

Washington Secretary of State. (1996). Election statistics [Online]. Available: http://www.wa.gov/sec/elections.htm

Wolfinger, R. E., \& Rosenstone, S. J. (1980). Who votes? New Haven, CT: Yale University Press.

Jeffrey A. Karp is a postdoctoral fellow at the Amsterdam School of Communications Research (ASCoR) at the Universiteit van Amsterdam and was formally a postdoctoral 
fellow with the New Zealand Election Study. His current research focuses on comparative political behavior. He is coeditor of Voters' Victory? New Zealand's First Election Under Proportional Representation, and his research has recently appeared in such journals as Political Research Quarterly, Political Behavior, Electoral Studies, and the Australian Journal of Political Science.

Susan A. Banducci is a postdoctoral fellow at the Amsterdam School of Communications Research (ASCoR) at the Universiteit van Amsterdam and was formally a postdoctoral fellow with the New Zealand Election Study. She has recently coauthored (with Jeffrey Karp) an article examining all mail elections in Oregon, which appears in Political Behavior. She is also coeditor of Voters' Victory? New Zealand's First Election Under Proportional Representation and has published other articles and book chapters on elections and voting behavior, gender and politics, and the initiative and referendum process. 